\title{
EFFECTS OF ILL-HEALTH COST ON MULTIDIMENSIONAL POVERTY: EVIDENCE FROM RURAL HOUSEHOLDS IN NIGERIA
}

\author{
Kazeem Oriyomi ABOABA
}

\author{
Address: \\ Department of Agricultural Economics and Farm Management, P.M.B 2240, Federal University of Agriculture, \\ Abeokuta, Nigeria. \\ E-mail: aboabakazeem@gmail.com
}

\begin{abstract}
Good health is important in the economy of any nation especially in the fight against poverty, poor health affects productivity and income of the workers and this will further deepen the incidence of poverty and ill-health. This study examined the linkage between ill-health cost and multidimensional poverty of rural households in Ogun state, Nigeria. Multistage sampling was used to select 240 households for the study. Data collected were analysed with descriptive statistics, economic cost of illness, multidimensional poverty index and logistic regression model. The result revealed that majority (95\%) of the households experienced malaria infestation, time cost of illness contributed most $(92.6 \%)$ to the total economic cost. Result revealed that $69 \%$ of households are multidimensionally poor. Furthermore, marital status $(\mathrm{p}<0.01)$, off-farm income $(\mathrm{p}<0.01)$, financial cost $(\mathrm{p}<0.01)$, days forgone production $(\mathrm{p}<0.1)$, time cost $(\mathrm{p}<0.01)$ and area cultivated $(\mathrm{p}<0.1)$ positively, and significantly influence multidimensional poverty status while household size $(\mathrm{p}<0.01)$, cooperative membership $(\mathrm{p}<0.05)$, public health care services $(\mathrm{p}<0.1)$ and health extension contact $(\mathrm{p}<0.01)$ have negative, and significant effect. The study concluded that increase in out of pocket expenditure as a result of illhealth cost increases poverty status, availability and access to public health facilities reduces poverty status, it was therefore recommended that public health facilities should be located nearer to the people with minimum social stratification that might discourage poor masses from its usage, essential drugs should be provided at subsidized rates as this will go a long way in reducing financial cost thereby reducing poverty status.
\end{abstract}

Keywords: Illness; Multidimensional Poverty; Deprivation

JEL: I32; D01

\section{INTRODUCTION}

Agriculture is an indispensable sector in Nigerian economy because it remains the only local source of food and natural fibre in spite of the dominance of petroleum, agriculture still plays vital roles in Nigerians economy, it contributed 23 percent to Nigeria's Gross Domestic Products (GDP) in 2017 (CBN, 2018). The sector provides employment for over $70 \%$ of Nigeria labour force, however, in spite of contribution of agriculture to national development; the sector has not received the appropriate public and institutional attention and had failed to contribute significantly to poverty alleviation. Poverty is dominant in rural Nigeria as a result of limited social services and infrastructural facilities (IFAD, 2012). OPHI (2017) reported that incidence of poverty in rural Nigeria rose from $68.4 \%$ in 2008 to $70 \%$ in 2017.

The Nigeria agricultural sector was dominated by subsistence farmers that were exposed to different health challenges which directly or indirectly affect their level of production as well as their living standards. Nigerian subsistence farmers spend as much as $13 \%$ of total household expenditure on treatment of malaria alone (Ajani and Ugwu, 2008). This gives enough evidence that the cost of combating diseases and health problem by farmers is quite huge. Large out of pocket health expenditure as a result of ill-health can have a major impact on financial status of rural households and can push them to poverty. They are likely to reduce their expenditure on basic items or sell off their productive assets in order to cope with health costs. However, developing countries which Nigeria is inclusive need good health and productive agriculture to fight against poverty; poor health affects the productivity and income of the workers and this will further deepen the incidence of poverty and ill-health (IFPRI, 2007). Although there are growing literatures on effect of ill- health on poverty status of farmers, previous studies failed to adopt a holistic approach to the problem of farmers' health and poverty in rural communities, previous studies used uni-dimensional poverty measures such as income and expenditure, this studies differs from other studies as it employs a multidimensional poverty measures that complements money-based measures by considering multiple deprivations and their overlap, as it is related to Sen's conception of capabilities. The study also identifies illness suffered by the households and estimate cost incurred as a result of ill-health.

\section{DATA AND METHODS}

The study was carried out in Ogun State Nigeria. Multistage sampling procedure was used for the study; the first stage was a random selection of four (4) Local 
Government Areas (LGAs) out of the twenty (20) Local Government Areas (LGAs) in the state, the second stage was a random selection of three (3) villages from the selected LGAs, the last stage was a purposive selection of twenty (20) households from the selected villages making two hundred and forty (240) respondents, however, during data clean up only 225 questionnaire were fit for analysis representing $94 \%$ of the total responses.

\section{Cost of illness}

This study adopted and modified Cost of Illness (COI) procedure used by Sauerborn et al., (1996) and Akinbode et al., (2011) with the inclusion of preventive cost, COI was used to capture the economic cost of illhealth, it is as specified in the Eq. (1-3).

Financial Cost

$F_{c}=\sum_{j=0}^{n}\left(F_{d}+F_{m}+F_{t}+F_{s u}\right)$

Time cost of illness

$T_{c}=\sum_{j=0}^{n}\left[\left(T_{s i} * a_{s i} * w\right)+\left(T_{c i} * a_{c i} * w\right)\right]$

Economic cost $=\sum_{j=0}^{n}\left(F_{c}+T_{c}\right)$

The preventive cost $P_{c}$ was added to the cost and it was specified as the Eq. (4).

Economic cost $=\sum_{j=0}^{n}\left(F_{c}+T_{c}+P_{c}\right)$

Where:

$F_{d}$ financial cost of drugs, herbs, etc. ( $)$;

$F_{m}$ financial cost of medical consultancy (N);

$F_{t}$ financial cost of travel (N);

$F_{s u}$ financial cost of subsistence (feeding) ( $)$;

$T_{c}$ total time cost (number of days forgone production);

$T_{s i}$ time cost of sick person (number of days forgone production);

$a$ age coefficients (number);

$s$ sick individual (number);

$w$ daily wage rate $(\mathrm{N})$;

$T_{c i}$ time cost of caregiver (s) (number of days forgone production);

$c$ caregiver (number);

$F_{c}$ total financial cost of health care.

To estimate the number of days of forgone production activities required in estimating the time cost of illness, following Akinbode et al., (2011) the man days was estimated using the average male adult work for about 8 hours a day. Thus, the actual total hours devoted to farm work was converted to male adult equivalent by multiplying those of male by 1 and those of female by 0.75 and those of children by 0.5 , an assumption that average working condition prevail.

The age coefficient " $a$ " represents productivity coefficient and this takes on the following values following Sauerborn et al., (1996) and WB (1993):

Age $<17$ years $=0.5$

18 -40years $=1$

41-55years $=0.75$
$56-65$ years $=0.67$ and

$>65$ years $=0.5$.

\section{Multidimensional Poverty Index}

The Multidimensional Poverty Index (MPI) complements money-based measures by considering multiple deprivations and their overlap. Adopting from the MPI of Alkire et al., (2011) and Aboaba et al., (2019), two dimensions and seven indicators were added to the 3 dimensions and 10 indicators of the MPI in other to better capture the multidimensional poverty in the study area, these additional dimensions are infrastructure and social capital while the indicators include transportation facilities, hospital, market, roads, group and networks, information and communication, empowerment and political actions, the maximum score is $100 \%$ or 1 with each dimension (Education, Health, Standard of Living, Infrastructure and Social capital) are equally weighted. A household was considered multi-dimensionally poor if the total deprivation is equal to or greater than $20 \%$ or 0.2

\section{Multidimensional Poverty Indices}

Following Alkire et al. (2011), the multidimensional poverty index was expressed as the Eq. (5).

$M P I=\mathrm{H}^{*} \mathrm{~A}$

Where:

$H$ the multidimensional headcount ratio which is the proportion of people who are poor, the multidimensional head count ratio $(H)$ is expressed as the Eq. (6).

$\mathrm{H}=\frac{\mathrm{q}}{n}$

Where:

$q$ the number of people who are multi-dimensionally poor and $\mathrm{n}$ is the total population.

$A$ the intensity (or breadth) of poverty which is the average deprivation score of the multi-dimensionally poor people and can be expressed as the Eq. (7).

$A=\frac{\sum_{i=1}^{n} c_{i}(k)}{q}$

Where:

$c_{i}(k)$ the censored deprivation score of individual $i$ and $q$ a number of people who are multi-dimensionally poor.

\section{Logistic Regression Analysis}

Logistic regression analysis was used to estimates the effect of burden of disease on multidimensional poverty status of the households, the model was specified as the Eq. (8).

$Y_{i}=\ln \left(\frac{p}{1-p}\right)=\alpha_{0}+\sum_{i=1}^{16} \alpha Z+e_{t}$

Where:

$Z$ independent variables specified in the Table 1 .

$Y_{i}$ the multidimensional poverty status (1= multidimensionally poor, $0=$ otherwise); 
$\alpha_{0}$ intercept;

$\alpha_{1}-\alpha_{16}$ parameters to be estimated;

$e_{t}$ error term or disturbance term.

\section{RESULTS AND DISCUSSION}

\section{Socioeconomic characteristics}

The results (Tab. 2) revealed that the mean age of the household heads was 54 years; this implies that most of the household heads were old, non-energetic and not within their productive age, this may have a positive influence on their poverty status. Larger proportion of the household heads were male. This implies that there were more male than their female counterparts. This can be attributed to the fact that farming is tedious and requires a lot of energy which most female might not be able to provide. The average size of the household is approximately 6 persons; this implies that most of the households have a fairly large household size which they might employ on their farms. More than half of the household heads were married. The implication is that most of the household heads have implanted sense of responsibility as marital status prompts commitment to business because of the family needs that must be met. On the average, the household heads spent 6 years in school. This implies, that most of the household heads had basic education and this might influence their adoption of innovative practices which will improve their poverty status. Lower percent and half of the household heads were members of cooperative society and farmer's organization respectively. The mean farming experience was approximately 26 years. This implies that most of the household heads had enough experience about farming and this may influence their productivity and poverty status. Most of the household heads were smallholders with average farm size of 2.8 hectares. This result revealed that most of the farmers were smallholders and this may have a positive influence on household poverty status.

Table 1: Definition and measurement of variables

\begin{tabular}{lllc}
\hline Variable & Definition & Measurement & Expected sign \\
\hline $\mathrm{Z}_{1}$ & age of household heads & (years) & + \\
$\mathrm{Z}_{2}$ & sex of household heads & (Dummy, 1=male, 0=female) & - \\
$\mathrm{Z}_{3}$ & household size & (number of persons) & + \\
$\mathrm{Z}_{4}$ & marital status of household heads & (Dummy, 1=married, 0=otherwise) & + \\
$\mathrm{Z}_{5}$ & off-farm income & (naira) & - \\
$\mathrm{Z}_{6}$ & level of education of household heads & (years) & - \\
$\mathrm{Z}_{7}$ & cooperative membership & (Dummy, 1=member, 0=otherwise) & - \\
$\mathrm{Z}_{8}$ & farmers organization & (Dummy, 1=member, 0=otherwise) & - \\
$\mathrm{Z}_{9}$ & farming experience of household heads & (years) & - \\
$\mathrm{Z}_{10}$ & preventive cost & (naira) & \pm \\
$\mathrm{Z}_{11}$ & financial cost & (naira) & + \\
$\mathrm{Z}_{12}$ & days forgone production & (days) & + \\
$\mathrm{Z}_{13}$ & time cost & (naira) & + \\
$\mathrm{Z}_{14}$ & area cultivated & (hectare) & - \\
$\mathrm{Z}_{15}$ & availability of public health care & (Dummy, 1=available, 0=otherwise) & - \\
$\mathrm{Z}_{16}$ & contact with health extension & (Dummy, 1=had contact, 0=otherwise) & - \\
\hline
\end{tabular}

Source: Authors review of literatures

Table 2: Descriptive Statistics of the Sample data

\begin{tabular}{lrr}
\hline Variable & $\begin{array}{r}\text { Mean } \\
\text { Age }\end{array}$ & $\begin{array}{r}\text { Standard } \\
\text { Deviation }\end{array}$ \\
\hline Agex & 54.3 & 14.1 \\
Household size $^{+}$ & 0.7 & 0.4 \\
Marital status $^{+}$ & 5.9 & 2.4 \\
Level of education $_{\text {Cooperative membership }}^{+}$ & 0.6 & 0.5 \\
Farmers association $^{+}$ & 5.5 & 4.9 \\
Farming experience $_{\text {Area cultivated }}$ & 0.2 & 0.4 \\
Ant & 26.4 & 0.5 \\
\hline
\end{tabular}

Note: ${ }^{+}$In case of dummy variables, proportions were used instead of means.

Source: Field survey data analysis, 2018 


\section{Illness Experienced by the Households}

For the period of 6 months (Table 3), back pain illness was suffered by almost all of the rural households, high proportion of the households experienced fever, malaria infestation was suffered by almost all of the rural households. Less than half of the households suffered guinea worm, almost half suffered typhoid infestation, a quarter of the households suffered measles, more than half of the households experienced rheumatism. More than a quarter of the households suffered tuberculosis infestation while proportion of the households suffered waist pain. This implies that majority of the households suffered malaria, followed by back pain, waist pain, fever, rheumatism, typhoid, guinea worm, tuberculosis and measles respectively.

Table 3: Illness Experienced by the Households

\begin{tabular}{lrrr}
\hline Variable & $\begin{array}{c}\text { Frequency } \\
\text { (Episodes) }\end{array}$ & Percentage & Rank \\
\hline Perceived illness & & & \\
Back pain & 210 & 93 & $2^{\text {nd }}$ \\
Fever & 195 & 87 & $4^{\text {th }}$ \\
Malaria & 213 & 95 & $1^{\text {st }}$ \\
Guinea worm & 82 & 36 & $7^{\text {th }}$ \\
Typhoid & 103 & 46 & $6^{\text {th }}$ \\
Measles & 56 & 25 & $9^{\text {th }}$ \\
Rheumatism & 118 & 52 & $5^{\text {th }}$ \\
Tuberculosis & 66 & 29 & $8^{\text {th }}$ \\
Waist pain & 200 & 89 & $3^{\text {rd }}$ \\
\hline Source: Fied & 2018 & &
\end{tabular}

Source: Field survey data analysis, 2018

\section{Economic Cost of Illness}

On the average, the economic cost of illness for the period under consideration (six months) (Table 4) was $\$ 158,073.72$. The total financial cost was $\$ 11,116.92$, the total time cost was $\$ 146,305.70$ and the total preventive cost was $\$ 651.70$. The total financial cost contributed $7.03 \%$ to the total economic cost, cost of drugs and herbs contributed $74.24 \%$ to the total financial cost and $5.22 \%$ to the total economic cost, cost of medical consultancy contributed $12.40 \%$ to the financial cost and $0.87 \%$ to the total economic cost, cost of sustenance (feeding) contributed $6.76 \%$ to the financial cost and $0.48 \%$ to the economic cost while cost of travelling contributed $6.59 \%$ to the financial cost and $0.46 \%$ to the economic cost. The total time cost contributed $92.56 \%$ to the total economic cost and the time cost of sick person contributed $59.11 \%$ to the time cost and $54.71 \%$ to the economic cost, time cost of care giver contributed $40.89 \%$ to the total time cost and $37.84 \%$ to the total economic cost, preventive cost contributed $0.41 \%$ to the total economic cost. This implies that cost of drugs and herbs contributed most to the total financial cost and time cost of sick person contributed most to the total time cost, the total time cost contributed most to the total economic cost followed by financial cost and preventive cost respectively. This result is in consonance with the findings of Adekunle et al., (2016) that found out that time cost contributed most $(64.08 \%)$ to the economic cost of illness, followed by financial cost $(28.30 \%)$ and preventive cost $(7.62 \%)$ respectively. The results also support the findings of Akinbode et al., (2011) that found out that time cost of illness was a major contributor to the economic cost of illness.

\section{Deprivation Experienced by the Rural Households}

Almost all of the households were not deprived adequate nutrition, larger proportion did not experienced child mortality, high proportion have access to basic education, high proportion completed basic education, high proportion were not connected to national electricity grid, more than half were deprived clean water, more than half were deprived adequate sanitation, high proportion were deprived clean cooking fuel, half were deprived clean floor of home, high proportion did not own productive and households assets, more than half did not have hospital available within $2 \mathrm{~km}$ of their homes, more than half did not have neighbourhood markets to display their goods, more than half were deprived good transport facilities, high proportion did not received support from non-family members in times of hardship, high proportion were being excluded from social and cultural activities while more than half did not control over decisions affecting their lives (Table 5).

Table 4: Estimates of Cost of Illness

\begin{tabular}{lrrr}
\hline Variable & Amount ( $)$ & \% Cost & \% Total Cost \\
\hline Financial Cost & & & \\
i. Cost of drugs and herbs & $8,253.48$ & 74.24 & 5.22 \\
ii. Cost of medical consultancy & $1,378.82$ & 12.40 & 0.87 \\
iii. Cost of feeding & 751.64 & 6.76 & 0.48 \\
iv. Cost of travelling & 732.97 & 6.59 & 0.46 \\
1. Total Financial Cost & $11,116.92$ & 100.00 & 7.03 \\
Time Cost & & & \\
i. Time cost of sick person & $86,486.03$ & 59.11 & 54.71 \\
ii. Time cost of care giver & $59,819.67$ & 40.89 & 37.84 \\
2.Total Time Cost & $146,305.70$ & 100.00 & 92.56 \\
Preventive Cost & & & \\
3. Total Preventive Cost & 651.10 & 100.00 & 0.41 \\
4. Total Economic Cost & $158,073.72$ & & 100.00 \\
\hline Source: Field survey data analysis, 2018 & &
\end{tabular}


Table 5: Deprivation Faced by the Households

\begin{tabular}{|c|c|c|}
\hline Dimension & Frequency & Percentage \\
\hline \multicolumn{3}{|l|}{ Nutrition } \\
\hline Not Deprived & 212 & 94.22 \\
\hline Deprived & 13 & 5.78 \\
\hline \multicolumn{3}{|l|}{ Child mortality } \\
\hline Not Deprived & 197 & 87.56 \\
\hline Deprived & 28 & 12.44 \\
\hline \multicolumn{3}{|c|}{ Access to basic education } \\
\hline Not Deprived & 202 & 89.78 \\
\hline Deprived & 23 & 10.22 \\
\hline \multicolumn{3}{|c|}{ Completion of basic education } \\
\hline Not Deprived & 183 & 81.33 \\
\hline Deprived & 42 & 18.67 \\
\hline \multicolumn{3}{|c|}{ Connected to national electricity } \\
\hline Deprived & 165 & 73.33 \\
\hline Not Deprived & 60 & 26.67 \\
\hline \multicolumn{3}{|l|}{ Clean drinking water } \\
\hline Deprived & 129 & 57.33 \\
\hline Not Deprived & 96 & 42.67 \\
\hline \multicolumn{3}{|l|}{ Adequate sanitation } \\
\hline Deprived & 124 & 55.11 \\
\hline Not Deprived & 101 & 44.89 \\
\hline \multicolumn{3}{|l|}{ Clean cooking fuel } \\
\hline Not Deprived & 72 & 32.00 \\
\hline Deprived & 153 & 68.00 \\
\hline \multicolumn{3}{|l|}{ Clean floor of home } \\
\hline Not Deprived & 112 & 49.78 \\
\hline Deprived & 113 & 50.22 \\
\hline \multicolumn{3}{|l|}{ Ownership of assets } \\
\hline Deprived & 161 & 71.56 \\
\hline Not Deprived & 64 & 28.44 \\
\hline \multicolumn{3}{|c|}{ Availability of hospital within $2 \mathrm{Km}$} \\
\hline Deprived & 130 & 57.78 \\
\hline Not Deprived & 95 & 42.22 \\
\hline \multicolumn{3}{|c|}{ Availability of neighbourhood market } \\
\hline Deprived & 132 & 58.67 \\
\hline good road network & 93 & 41.33 \\
\hline \multicolumn{3}{|c|}{ Good transport facilities } \\
\hline Deprived & 121 & 53.78 \\
\hline Not Deprived & 104 & 46.22 \\
\hline \multicolumn{3}{|c|}{ Support in times of hardship from non-family members } \\
\hline Deprived & 142 & 63.11 \\
\hline Not Deprived & 83 & 36.89 \\
\hline \multicolumn{3}{|c|}{ Exclusion from social and cultural activities } \\
\hline Deprived & 165 & 73.33 \\
\hline Not Deprived & 60 & 26.67 \\
\hline \multicolumn{3}{|c|}{ Control of decision affecting life } \\
\hline Deprived & 125 & 55.56 \\
\hline Not Deprived & 100 & 44.44 \\
\hline
\end{tabular}

Source: Field survey data analysis, 2018

\section{Poverty Status of Rural Households}

The results presented in Table 5 revealed, that the multidimensional head count ratio was 0.69 which implies that $69 \%$ of the rural households are multidimensionally poor. That is $69 \%$ of people are in households with a malnourished person, no clean water, no electricity, no good health care services, no education, a dirt floor, unimproved sanitation, inadequate infrastructures, etc. The result is in line with the findings of Amao et al.,
(2017) that found out that the multidimensional headcount ratio in south-western Nigeria was $67.4 \%$, the intensity of poverty among the rural households in the study area was 0.41. This implies that on average the rural poor households were deprived $41 \%$ of the weighted indicators, that is they are deprived $41 \%$ of clean water, electricity, education, health services, improved sanitation. The result is similar to the finding of OPHI (2017) that found out that the intensity of poverty in Ogun state was $42.5 \%$. The 
multidimensional poverty index was 0.28 , this implies that the rural households are deprived in $28 \%$ of the total deprivations they could experience overall. These findings differ from that of OPHI (2017) and Amao et al., (2017) that found out that the multidimensional poverty status of Ogun state and south-western Nigeria are $11.2 \%$ and $31.8 \%$ respectively.

Table 6: Multidimensional Poverty Indices of Rural Households

\begin{tabular}{lr}
\hline Variable & Value \\
\hline Multidimensional Headcount Ratio (H) & 0.69 \\
Intensity of Poverty (A) & 0.41 \\
Multidimensional Poverty Index (MPI) & 0.28 \\
\hline Source: Field
\end{tabular}

Source: Field survey data analysis, 2018

\section{Effect of Ill-health Cost on Multidimensional Poverty Status}

The diagnostic test (Table 7) revealed the overall fit of the model at $1 \%(\mathrm{p}<0.01)$ level of significance, the Pseudo R squared showed that $91.9 \%$ variation in multidimensional poverty status was jointly explained by the explanatory variables. This shows that the model has a very high explanatory power. The marginal effects of household size revealed that if the size of the household increases by $1 \%$ the multidimensional poverty status of the rural households will reduce by $1.4 \%$, this result contradicts the findings of Awan and lqbal (2010) and Adekoya (2014) that reported a positive relationship between household size and probability of being poor, this was because most of the household members are matured enough to be working thereby contributing to the household income. The marginal effects of marital status showed that the poverty status of married household's increases by $12.6 \%$ compared to their counterparts. This is so because most of the married households have more of their household members to be children who are unproductive and yet take a big proportion of household income in terms of school fees, medical bills, food and clothing, this result corroborates the finding of Adekoya (2014). The marginal effects of off-farm income revealed that increase in offfarm income increases the likelihood of being poor; this was because the level of livelihood diversification among the households is low thereby resulting to low income. The coefficient of cooperative membership revealed that the poverty status of rural household heads that belonged to cooperative society is likely to reduce by $5.6 \%$ compared to their counterparts. The marginal effects of financial cost revealed that increase in financial cost would increase the probability of being poor by $0.5 \%$. This implies that increase in financial cost (drugs and herbs, consultancy, feeding and travelling) increase the poverty level of the rural households, this is so because large out of pocket expenditure on (drugs and herbs, consultancy, feeding and travelling) is catastrophic to the wellbeing of the household as they are likely to reduce their expenditure on basic items such as food or sell off their productive assets in order to cope with health costs thereby pushing them into poverty. This results corroborates the findings of Oparinde et al., (2018).

Table 7: Logit Regression Estimate of Effect of Ill-health Cost on Multidimensional Poverty Status Variable Coefficient Standard Error t-value P-value Marginal Effects

\begin{tabular}{|c|c|c|c|c|c|}
\hline & & & & \multicolumn{2}{|c|}{$(\mathrm{dy} / \mathrm{dx})$} \\
\hline$\overline{\text { Age }}$ & 0.130 & 0.081 & 1.600 & 0.109 & 0.002 \\
\hline Sex & -4.243 & 2.738 & -1.550 & 0.121 & -0.070 \\
\hline Household size & $-0.828 *$ & 0.439 & -1.890 & 0.059 & -0.014 \\
\hline Marital status & $7.642 * * *$ & 2.340 & 3.270 & 0.001 & 0.126 \\
\hline Off-farm income & $0.000 * * *$ & 0.000 & 5.740 & 0.000 & 0.000 \\
\hline Level of education & -0.047 & 0.095 & -0.500 & 0.619 & -0.001 \\
\hline Cooperative membership & $-3.391 * *$ & 1.599 & -2.120 & 0.034 & -0.056 \\
\hline Farmers association & 0.375 & 0.993 & 0.380 & 0.706 & 0.006 \\
\hline Farming experience & -0.077 & 0.055 & -1.400 & 0.161 & -0.001 \\
\hline Preventive cost & -0.002 & 0.003 & -0.740 & 0.461 & 0.000 \\
\hline Financial cost & $0.003 * * *$ & 0.001 & 3.570 & 0.000 & 0.005 \\
\hline Days forgone production & $0.109 * *$ & 0.045 & 2.430 & 0.015 & 0.002 \\
\hline Time cost & $0.000 * * *$ & 0.000 & -2.680 & 0.007 & 0.002 \\
\hline Area cultivated & $0.419 *$ & 0.236 & 1.780 & 0.076 & 0.007 \\
\hline Public healthcare services & $-9.303 * *$ & 4.641 & -2.000 & 0.045 & -0.154 \\
\hline Health extension contact & $-6.453 * * *$ & 1.690 & -3.820 & 0.000 & -0.107 \\
\hline Constant & $-10.454 *$ & 5.897 & -1.770 & 0.076 & \\
\hline \multicolumn{6}{|l|}{ Diagnostic test } \\
\hline Wald $\operatorname{chi}^{2}(16)$ & $60.53 * * *$ & & & & \\
\hline Prob $>$ chi $^{2}$ & $0.000 * * *$ & & & & \\
\hline Pseudo $\mathrm{R}^{2}$ & 0.919 & & & & \\
\hline Log likelihood & -11.857 & & & & \\
\hline Number of Observation & 225 & & & & \\
\hline
\end{tabular}


The marginal effects of the forgone production days revealed that if the number of forgone production days as a result of ill-health increases by $1 \%$, the poverty status of the rural household will increase by $0.2 \%$. This is so because ill-health reduces the healthy time of the households thereby reducing their level of production and income which will invariably push them into poverty. The marginal effects of time cost showed that increase in time cost of the sick individual and care giver would increase the probability of being poor by $0.1 \%$. This implies that increase in time cost increases the probability of being poor. This is so because the number of forgone production days would increase as a result of ill health thereby reducing their efficiency and income and further deepening the incidence of poverty and ill health (IFPRI, 2007). This result corroborates the findings of Adebayo $\boldsymbol{e t}$ al., (2012) and Oparinde et al., (2018). Similarly, Rhaji and Rhaji (2008) reported that health related indices had negative relationship with revenue generation and productivity among sampled household farmers.

The coefficient of area of farmland cultivated revealed that if the area cultivated increases by $1 \%$ there is likelihood that the poverty status of the poverty status of the household will increase by $0.7 \%$. This may be because larger farm size prevents the farming households from diversifying into off-farm and non-farm activities thereby limiting the amount of income generated which will invariably affect their standard of living. The marginal effects of health care provider revealed that availability of government clinic would reduce the likelihood of being poor by $15.4 \%$. This implies that the poverty status of rice farming households that have access to government clinics is likely to decrease compared with their counterparts that have no access to government clinics. This is so because households that have access to government clinics are likely to receive health care services at a cheaper cost (financial cost). This would increase their healthy time which would invariably translate to increase income and productivity, thereby stamping out poverty. The marginal effects of health extension worker revealed, that the poverty status of households that have contact with health extension worker, is likely to reduce by $10.7 \%$ compared to their counterparts that did not have contact with health extension worker.

\section{CONCLUSION AND RECOMMENDATION}

The study examined the linkages between ill-health cost and multidimensional poverty status of rural households. The result revealed that majority of the households suffered malaria illness followed by back pain, waist pain, fever, rheumatism, typhoid, guinea worm, tuberculosis and measles respectively. Time cost of illness contributed most to the total economic cost followed by financial cost and preventive cost respectively. It was revealed that higher proportion of people are in households with a malnourished person, no clean water, no electricity, no good health care services, no education, a dirt floor, unimproved sanitation, inadequate infrastructures, etc. it was further revealed that marital status $(\mathrm{p}<0.01)$, off-farm income $(\mathrm{p}<0.01)$, financial cost $(\mathrm{p}<0.01)$, days forgone production $(\mathrm{p}<0.1)$, time cost $(\mathrm{p}<0.01)$ and area cultivated $(\mathrm{p}<0.1)$ positively, and significantly influence multidimensional poverty status, while household size $(\mathrm{p}<0.01)$, cooperative membership $(\mathrm{p}<0.05)$, public health care services $(\mathrm{p}<0.1)$ and health extension contact $(p<0.01)$ have negative, and significant effect. The study concluded that increase in out of pocket expenditure as a result of ill-health cost increases poverty status, availability and access to public health facilities, reduces poverty status.

It was therefore recommended, that public health facilities should be located nearer to the people with minimum social stratification that might discourage poor masses from its usage. Essential drugs should be provided to the rural households at subsidized rates, as this will go a long way in reducing their financial cost, thereby reducing their poverty status.

\section{REFERENCES}

ABOABA, K. O., ADENLE, S. M., SOWUNMI, E. O., \& AKINADE, A. I. (2019). Nexus between Poverty and Livelihood Diversification among Rural Households in Nigeria: A Multidimensional Poverty Index Approach. International Journal of Advanced Research and Publications, 3(5):168-175. ISSN: 2456-9992

ADEKOYA, O. A. (2014). Analysis of Farm Households Poverty Status in Ogun States, Nigeria. Asian Economic and Financial Review, 4(3):325-340. URL: http://www.aessweb.com/pdf-files/aefr\%204(3),\%20325340.pdf

ADEKUNLE, A. K., ADEKUNLE, C. P., \& AIHONSU, J. O. Y. (2016). Effect of Health Condition on Technical Efficiency of Small-Scale Crop Farmers in Yewa Division of Ogun State, Nigeria. Nigerian Journal of Agriculture, Food and Environment, 12(2):138-143. URL: http://njafe.com/njafe2016v12n2/24Adekunle_et_al.pdf AKINBODE, S. O., DIPEOLU, A. O., \& IBRAHIM, D. A. (2011). Effects of Disease Burden on Technical Efficiency among Lowland Rice Farming Households in North Central Nigeria. World Journal of Agricultural Sciences,7(3): 359-369.

ALKIRE, S., ROCHE, J. M, SANTOS, M. E, \& SETH, S. (2011). Multidimensional Index 2011. Brief Methodological Note. Oxford Poverty and Human Development Initiative.

AMAO, O. J., AYANTOYE, K., \& FANIFOSI, E. G. (2017). An analysis of multidimensional poverty and its determinants in rural Nigeria. Journal of Development and Agricultural Economics, 9(11): 303-311. DOI: https://doi.org/10.5897/JDAE2017.0857

AWAN, M. S., \& IQBAL, N. (2010). Determinants of urban poverty: The case of medium sized city in Pakistan. "PIDE-Working Papers 2010:60, Pakistan Institute of Development Economics. pp. 3-19. DOI: https://www.jstor.org/stable/43831358?seq=1

CBN. CENTRAL BANK OF NIGERIA STATISTICAL BULLETIN, (2018)

IFAD. INTERNATIONAL FUND FOR AGRICULTURAL DEVELOPMENT (2012). Enabling Poor People to Overcome Poverty. URL: http://www.ifad.org . Accessed August, 2012. 
IFPRI. INTERNATIONAL FOOD AND POLICY RESEARCH INSTITUTE BULLETIN, (2007): URL: http://www.fpri.org.

OPARINDE, L. O., OGUNBUSUYI, O., ATURAMU, O. A., \& OLADIPO, C. O. (2018). Food Crop Farmers' Health and Poverty Status Nexus in Ondo State, Nigeria. Journal of Poverty, Investment and Development, 43: 4755. ISSN 2422-8397

OPHI. OXFORD POVERTY AND HUMAN DEVELOPMENT INITIATIVE (2017). OPHI Country Briefing 2017: Nigeria. URL: www.ophi.org.uk/multidimensional-poverty-index/
RHAJI, M. A. Y., \& RHAJI, F. R. (2008). Implication of Household Status on Farm Income, Food Insecurity and poverty in Nigeria. Agricultural journal, 3(3): 241-247. DOI: https://medwelljournals.com/abstract/?doi=aj.2008. 241.247

SAUERBORN, R. N., NOUTAGA, A., HIEM, M., \& DIESFELD, H. F. (1996). Seasonal Variation of Household Costs of Illness in Burkina Faso. Social Science and Medicine, 43(3): 281-290. DOI:10.1016/0277-9536(95)00374-6.'

WB. WORLD BANK (1993). World Development Report: Investing in Health. Oxford University Press, New York. 